\title{
STUDIES ON EXPERIMENTAL RICKETS.
}

VI. THE EFFECTS ON GROWING RATS OF DIETS DEFICIENT IN CALCIUM.

\author{
BT E. V. MCCOLLUM AND NINA SIMMONDE
}

(From the Laboratory of the Department of Chemical Hygiene, Sehool of Hygiene and Public Health, Johns Hopkins University, Baltimore),

AND

\section{P. G. SHIPLEY AND E. A. PARK}

(From the Department of Pediatries, Johns Hopkins University, Baltimore) (Received for publieation, June 6th, 1921.)

Plates XXV to XXIX. (Figures I-10.)

\section{PART I.}

In the first paper of this series (2) we placed on record a series of faulty diets, which, when fed to the growing rat, caused pathological conditions of different kinds to develop in the skeleton. The pathological condition induced in the bones by some of the diets bore marked resemblances to those which characterize rickets in the human being. The diets were, relatively speaking, simple in their composition; their faults were deficiencies in fat-soluble $\mathbf{A}$, calcium, phosphorus, excess of calcium, etc. In an accompanying paper (3) we brought forward experimental proof of the remarkable influence exerted by cod liver oil on the deposition of lime salts in the bone of the rat. In rats which had lost the power to deposit lime salts in the epiphyseal cartilage as the result of the prolonged administration of certain faulty diets, the addition of cod liver oil to the diet without other change quickly restored the lost power to the organism. In subsequent communications we have brought forward evidence to indicate that in the presence of an insufficient amount of an organic factor in the diet-which provisionally we call fat-soluble A-a lowering of the phosphate content of the diet below a certain level-the calcium being present in optimal or above the optimal proportion, and all other constituents of the diet being in a proportion not far from the optimal-may cause changes of a pathological nature to develop in the skeleton which have all the gross and histological char- 
acteristics of rickets. When the deficiency in the phosphate content of the diet was completely compensated for, however, by the addition of the phosphate ion (the deficiency in fat-soluble $A$ still existing) the changes which developed in the skeleton were not those of rickets, but of osteoporosis. Our experiments have shown over and over again that bone is a labile tissue, and that the character of its growth can be easily influenced through the diet, and that gross deformities of the skeleton, however much they may resemble those of rickets in the human being, can not be aceepted as proof of rickets. The proof of the production of rickets must be sought in the histological changes in the bones themselves.

In papers which are forthcoming we shall attempt to describe the changes which result from restricting young rats to diets in which the fault is twofold; e.g., low calcium with low fat-soluble A, high calcinm with low fat-soluble $A$, and low calcium with liberal amounts of cod liver oil (high fat-soluble A?). We shall also discuss the effects on the young rat of diets low in calcium, but supplemented with the vegetable oils and varying amounts of butter fat, and of high caleium with fats of various origins. In the present communieation we describe the effects on growth and the changes in the skeleton which result from restricting the intake of caleium, the diet being in all other respects suitably constituted.

In interpreting the data presented in these papers it should be appreciated that modern researches in the field of nutrition have established the validity of the working hypothesis proposed by $\mathrm{Mc}$ Collum and Davis (5) in 1915. According to this hypothesis, a diet, to be satisfactory for nutrition during growth or for the maintenance of well-being in the adult over a prolonged period, must furnish the following elements or complexes. It must contain proteins in satisfactory amount. The amount of protein necessary will depend upon its quality, and its quality' in turn is the result of its composition with respect to the several amino-acids which are indispensable for the construction or repair of body tissues. Proteins from different sources differ greatly in their constitution in these respects. Nine inorganic elements in appropriate compounds are indispensable. These are sodium, potassium, magnesium, calcium, iron, phosphorus, chlorine, sulphur and iodine. With the exception of sulphur, which must be supplied in the form of the organic complex, cystine, these inorganic elements are all readily assimilated and utilized in the form of mineral salts, such as the chlorides and phosphates of the alkalies and 
494 E. v. MCCOLLUM, N. SIMMONDS, P. G. SHIPLEY AND E. A, PARK.

alkaline earths. The food must furnish suffieient energy-yielding substances in the form of carbohydrates or fats. The one indispensable complex in this class is glucose. Either glucose or a substance capable of yielding it must be present. The diet must likewise furnish sufficient water, and in the rat at least two still uncharacterized dietary factors now ordinarily called " vitamines." In man a third factor in this elass, the antiscorbutic substance, is essential.

Much of the research in the laboratory of the Department of Chemical Hygiene during the past few years has been directed toward the study of the quality of each dietary factor in each of our more important foodstuffs of animal and vegetable origin. It has been accomplished through the application of our biological method for the analysis of a food. Following the studies of the properties of individual dietary constituents numerous experiments were carried out to determine the extent to which two or more natural foods when combined enhance each other's protein values, and mutually supplement each other's deficiencies (6).

In the course of the investigations last referred to we employed a number of diets of considerable complexity for the purpose of determining whether, when the selection was limited to such vegetable products as are functionally storage tissues of plants, viz., seeds, tubers and roots, together with the highly specialized muscle tissue of animals, a wide variety of selection could form a suitable source of nutriment. In many of the studies in this series we observed deformities suggestive of rickets. Diets composed of cereals, legume seeds and muscle meats were especially likely to induce rickets-like deformities. We came to appreciate that such food mixtures were decidedly deficient in calcium and in fat-soluble $A$, and to a somewhat lesser degree in phosphorus. When we undertook a systematic analysis of the nature of the factors which operated to influence the skeletal changes observed, we judged it wise first to make the analysis of those food mixtures with which we had much experience, and accordingly in the first paper of this series is deseribed the production of ricketslike conditions by diets of a simpler charaeter. We have continued, however, in many instances, to restriet our animals to rather complex food mixtures such as are deseribed in this paper. The several individual factors in each of these more complex food mixtures we are now able to evaluate with considerable accuracy, and the food mixtures serve our purpose well, notwithstanding the fact that at first glance the formulas may appear unnecessarily complex and confusing. In 
reality they can be regarded as nearly as simple as if derived from purified foodstuffs supplemented with small additions of articles espeeially rich in one or another of the uncharacterized dietary essentials.

The diets employed in securing the data discussed in this paper were all fairly satisfactorily constituted with respect to all dietary factors except calcium. When casein or steak was added, the mixture was improved both with respect to protein and phosphorus. Cereal and legume seed mixtures, no matter how complex, never furnish protein of the optimal quality, and their phosphorus content is somewhat below the plane at which nutrition is best promoted. Such mixtures fall far short of meeting the need of the body for calcium during growth, and, no matter how well they may be supplemented, malnutrition will result from specific starvation for calcium unless a supplementary source of supply of it is made available. As important as phosphate additions, but far less important than additions of calcium in such diets, is an abundant supply of fat-soluble A. Diets similarly constituted, but derived in great measure from degerminated cereal products, will be much more faulty with respect to each of these factors than when entire seed kernels are used.

The animals used in these experiments were confined for the periods indicated by the accompanying charts to diets in which the main defect was deficiency in caleium. In order to avoid confusion from the possible effects of variables in the diet of a minor eharacter, such as smali differences in the quality of the protein or in the quantity of phosphorus or of fat-soluble A, we prepared the diets in such manner that these three nutrient essentials were made more abundant than in other experiments. If in such diets as we are discussing sufficient calcium is added, this will improve their biological value to an extent which can be detected in increased vitality as shown by span of life, fertility and diminished mortality among the young. Sinee the acidity of the seed or seed and steak mixture might affect in some way the growth of the osseous tissue, we neutralized this in some diets by the inclusion of an appropriate amount of sodium bicarbonate.

The following diets were employed:

No. 2684.

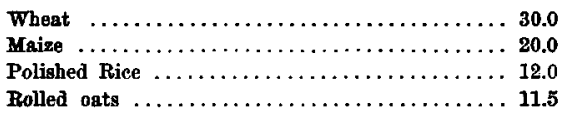




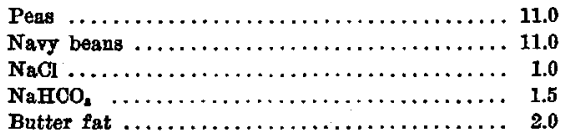

Ration 2684 is characterized by a marked deficiency in calcium. Since the ash of seeds is distinctly acid, ranging from the equivalent of 2.63 e.c. to 68.34 e.c. N/ 1 solution per 100 grams, we added in this case 1.5 gms. of sodium bicarbonate per $100 \mathrm{gms}$. of ration. The diet was thus made to contain a slight excess of bases over acids. For lack of calcium very little growth took place. This same food mixture with the sodium bicarbonate replaced by calcium carbonate induced optimal growth in the first generation, but, apparently owing to a deficiency of the food in phosphorus the later generations became nndersized and the mortality among the young was high. On the diet of Lot 2684 the animals aged very early.

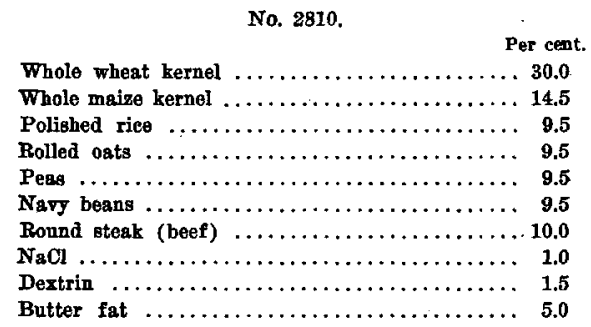

Ration 2810 was closely similar to ration 2684 , except that it contained 10 per eent. of round steak. This addition improved the quality of the seed proteins in a degree which can easily be demonstrated experimentally. It also raised the phosphorus cortent from .3047 to $.3726 \mathrm{gm}$. per $100 \mathrm{gms}$. of mixture, at the same time increasing the acidity of the diet, because of the mineral content of the cereal and legume mixture, from the equivalent of 16.61 e.c. $\mathrm{N} / \mathbf{1}$ base solution to 5.75 e.c. N/1 acid solution per 100 gms. of the ration as fed. These rats were, therefore, on the same defieient intake of calcium as were lot 2684, but had much more phosphorus and a more acid food supply. The content of the fat-soluble $\mathrm{A}$ in their diet was also higher than that of Lot 2684 (Chart 1), but the latter were supplied with enough of this factor to fully meet the needs of the growing rat when all other dietary factors are satisfactory. 


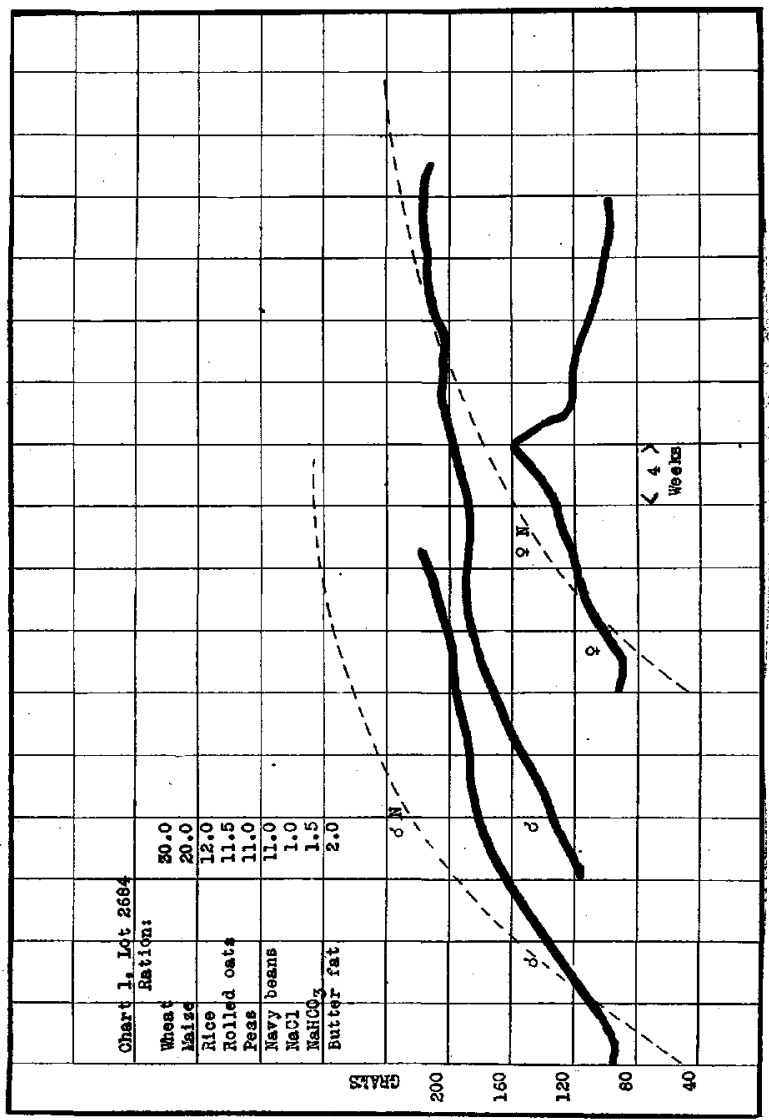


No. 2436. (Control Experimental Ration.)

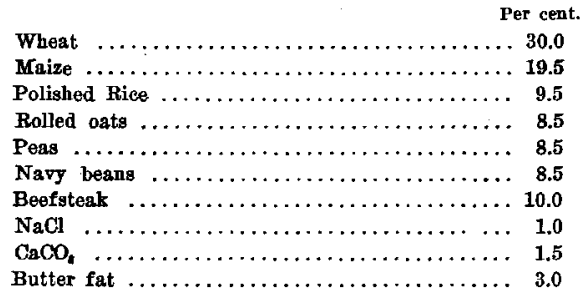

Ration 2436 was like ration 2810 , except that the dextrin of the latter was replaced by 1.5 per cent. of ealeium carbonate. This addition had a most remarkable effect in improving the quality of the diet. The animal appeared to be in the optimal condition and a family restricted to this diet appeared in the fourth generation to be entirely normal. One female of the fourth generation suceessfully weaned three litters (17 young).

No. 2731.

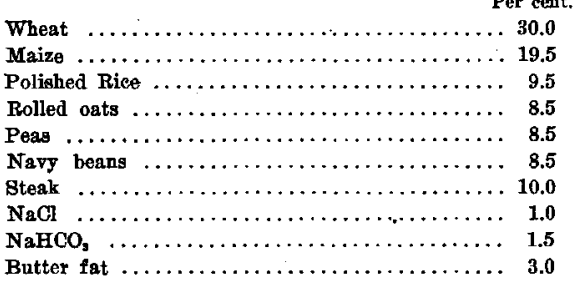

Ration 2731 was almost identical with ration 2810 . It differed in containing 1.5 per cent. of sodium bicarbonate, which changed it from a distinetly acid to a slightly alkaline reaction. The animals placed upon it became short and stocky, were rough looking and died early.

No. 2435. (Control Experimental Ration.)

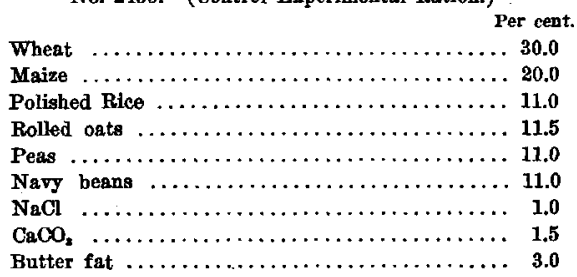


Ration 2435 differed in its properties from ration 2731 in three respects. The former had a lower protein content and was poorer in phosphorus, because it lacked the beefsteak which the latter contained. Furthermore, it contained 1.5 per cent. of caleium carbonate instead of sodium bicarbonate. These modifications made a remarkable difference in the growth and vitality of the animals. Lot 2435 grew normally and showed high fertility, but the infant mortality was high. They deteriorated from generation to generation, because of the shortage of phosphorus, and the relatively poor quality of proteins. This group should be compared with Lot 2436 (Chart 2).

No. 2581.

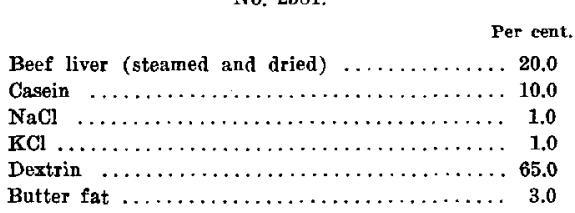

Ration 2581 was of good quality with respect to all constituents other than calcium, in which it was very deficient. The acidity of this food, owing to the high content of phosphorus and sulphur derived from liver and casein, was very great, and aside from the lack of ealcium was the only known fault. It is of great interest from the standpoint of the establishment of the validity of our method of interpretation of the canses of the bone lesions, diseussed in these experiments, to compare the histological picture seen in animals restricted to diets having the same faults, but derived ehiefly from such widely different sources as cereals and legume seeds in one instance, and liver, casein, dextrin, butter fat and salts in the other. The effeets on the bones were very similar.

On the diet of Lot 2581 all rats died very early. They were short, stunted, thin animals, with serious deformities of the thoraces.

This diet modified by the addition of calcium carbonate to the extent of 1.5 per cent., and without the addition of butter fat, induced approximately normal growth and fertility. There was no evidence of rachitic deformities. All the fat-soluble $A$ and a specific antirachitic substance, if there is such a substance, were derived entirely from 25 per cent. of liver in the diet. 
500 E. v. MCCOLLUM, N. SIMMONDS, P. G. SHIPLEY AND E. A. PARK.

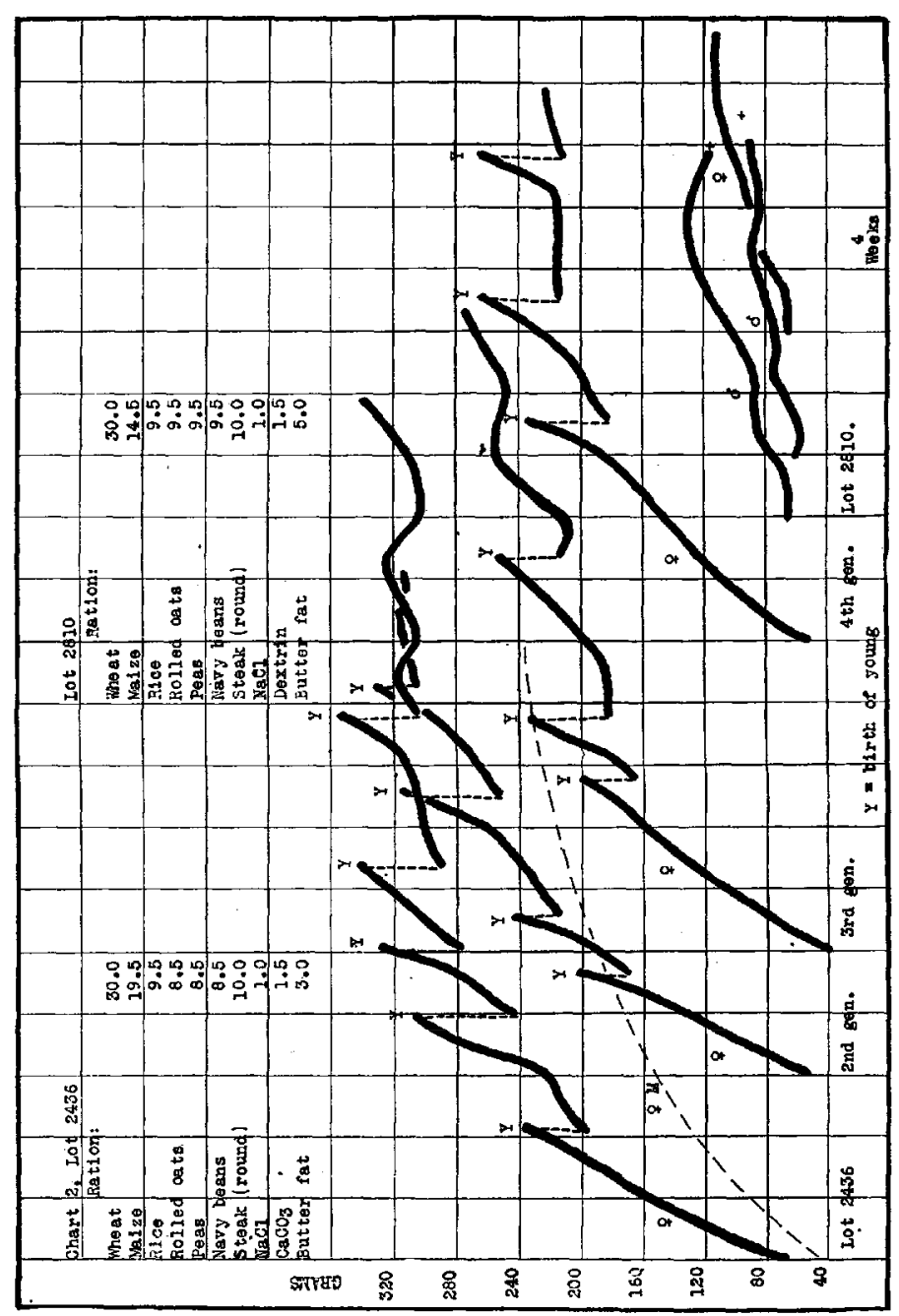




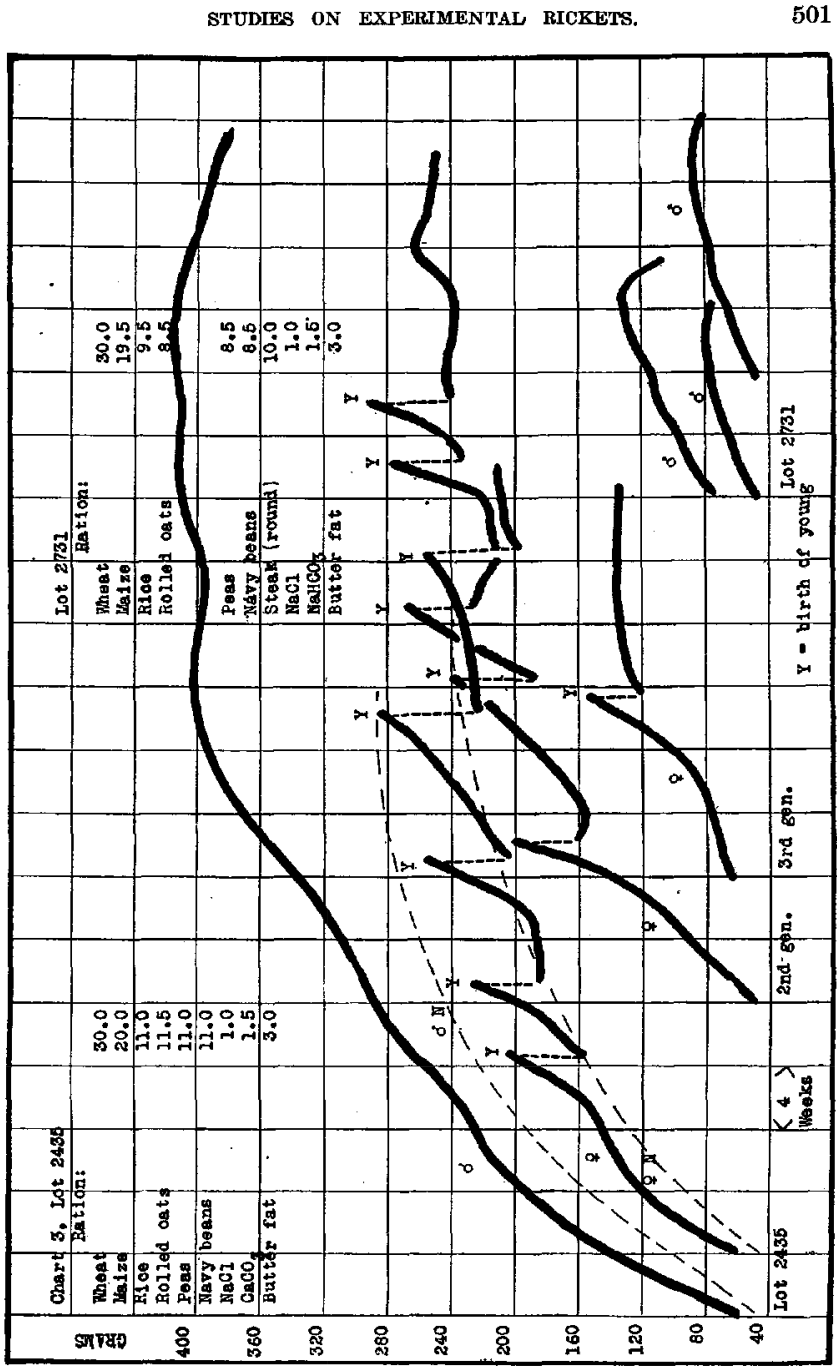


502 E. V. MCCOLLUM, N. SIMMONS, P. G. SHIPLAYY AND L, A. PARK,

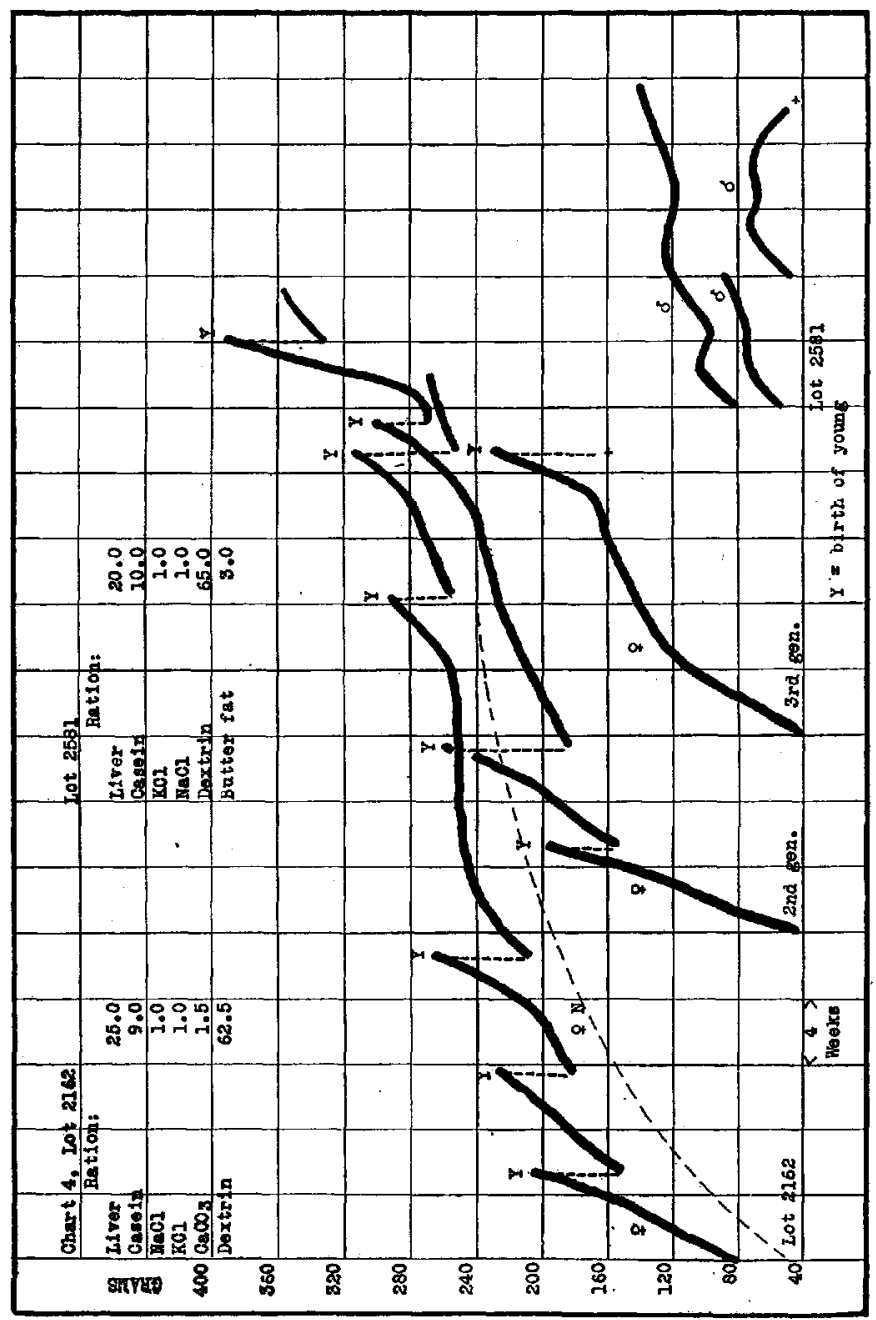


No. 2809.

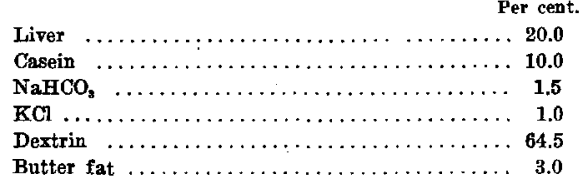

This ration was exactly similar to ration 2581, except that the sodium chloride was replaced by sodium bicarbonate. This neutralized the acidity of the former diet. That the reaction of the food within the limits of variation seen in this series of diets is not a factor of importance, the similarity in the character of the bone changes clearly show. There is no evidence that the neutralization of the acidity of the ration 2809 by the inclusion of sodium bicarbonate had any beneficial effect upon the animals. The gravity of the calcium deficiency was so great that the rats restricted to it were ruined by this deficiency alone. They developed deformities similar to those seen in the rats on ration 2581 (Chart 4).

No. 2143. (Control Experimental Ration.)

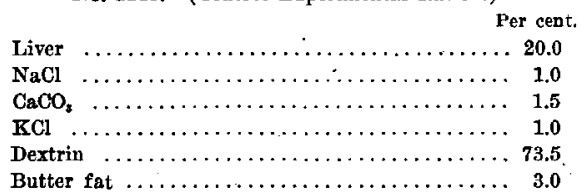

Ration 2143 differed from ration 2809 in that it contained no casein, and all of its protein was derived from 20 per cent. of liver; and also in that it contained 1.5 per cent. of caleium carbonate. Even with the lower protein supply the animals were able, when a supply of calcium was available, to develop in a fairly satisfactory manner and to produce and rear some young. They showed no evidences of the deformities seen in Lot 2809 .

\section{PART II.}

The earliest attempts to produce rickets in animals were made by feeding diets which were low in calcium. After the anatomical studies of Pommer had made elear that the fundamental lesions of the disease, in so far as the skeleton was concerned, were defects in the 
504 E. v. MCCOLLUM, N. SIMMONDS, P. G. SHIPLeY AND E. A. PARK.

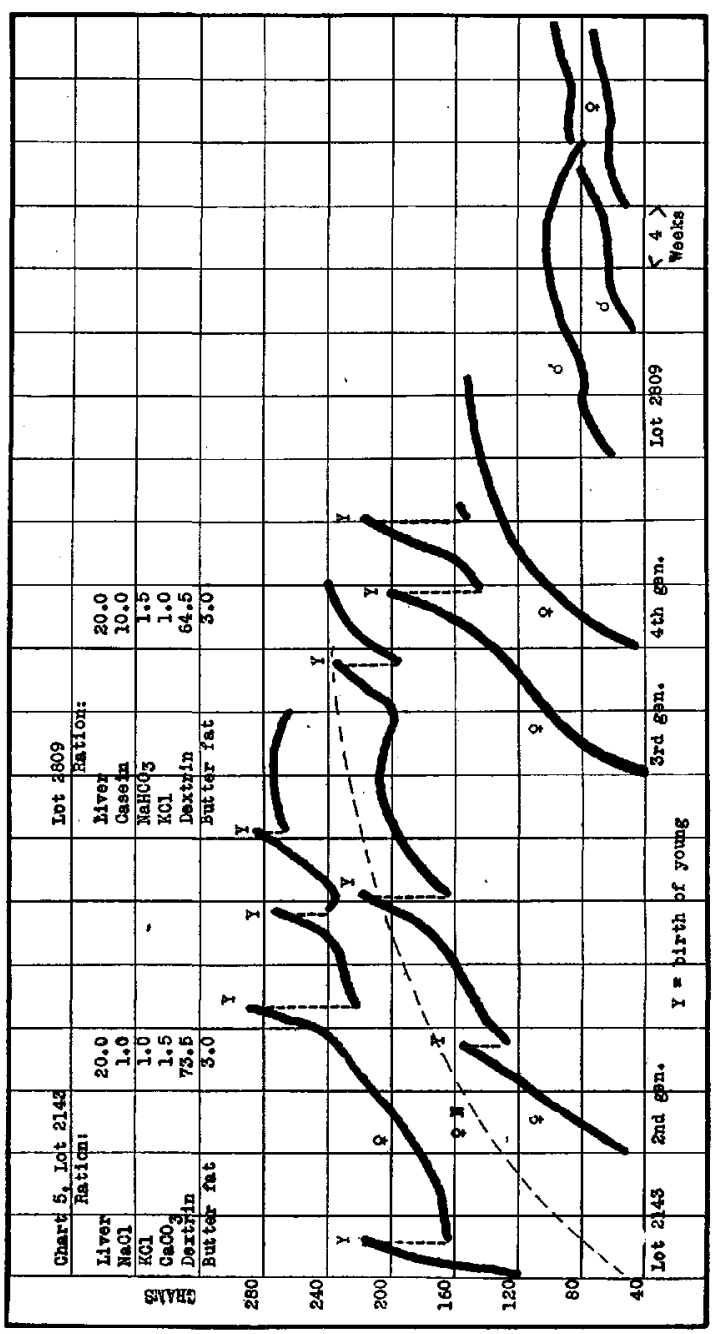


calcification of cartilage and bone, it seemed logical to conclude that a deficiency in the intake of calcium might be the canse of the disease. Numbers of investigators have made atternpts to produce rickets by feeding diets insufficient in ealcium salts. At the present time, however, it is difficult to know what value to place upon their work. In the first place, it is almost impossible to decide whether the changes described in the bones of their animals were or were not equivalent to human rickets. In the second place, it is by no means easy to make certain that the deficiency in calcium in their diets was the sole fault. Almost all of the work of the investigators of this particular problem was performed prior to 1910. Before that time a diet which contained protein, carbohydrate and fat in sufficient amounts to furnish the energy requirements of the body, together with a supply of certain inorganic salts, was considered adequate for the maintenance of life and normal development over any number of generations. It stands to reason, therefore, that with the increased knowledge of today the recognition of dietary defects is easy in formulas which 15 years ago passed as deficient only as regards their content of calcium. A diet used by one of the investigators in question will suffice as an example. Dibbelt (1) maintained the dogs used in his experiments on a diet composed of horse meat, a carbohydrate (rice starch) and sodium chloride. This ration is low in calcium certainly, but it is also deficient in fat-soluble $A$, water-soluble $B$, and probably in the antiscorbutic substance as well. Moreover, the protein is not of the best quality. It will be seen that, even if there were no dispute as to whether the disease which was produced in puppies by this diet was rickets or not, it would be impossible to say that the deficiency in calcium was the cause.

The gross changes in the skeleton and the alterations in the finer structure of the bones of the rats placed on the various faulty rations described, which had in common a deficiency in calcium, were so similar that a single deseription will serve for all.

The bodies of the animals at autopsy were very much undersized and showed quite characteristie lesions. The coat was rough and the hair was irregular in length. The skulls were often very thin and easily compressible. The eyes were normal. The incisor teeth were very brittle, yellow and easy to extract. The epiphyses of the long bones, especially at the wrist and knee, were enlarged. The shafts of the bones were slender. The thoraces were much flattened from side to side, slender, and marked by deep grooves along the eostochondral 
junctions. When the thorax was opened, the junctions of the ribs with their cartilages were enlarged and there was marked angular deformity (Fig. 1). This extreme degree of angular deformity at the junctions of the ribs and the cartilages exceeded that found in the ribs of rats on a diet already described, low in fat-soluble $A$ and phosphorus (4). The thymus was atrophied. The spleen was frequently greatly enlarged. There was little, if any, subeutaneous or visceral fat. The gonads were atrophic. The long bones cut easily. There were, as a rule, no fractures to be found in any of the bones except the ribs, which were usually studded throughout their length with the calluses of multiple healing fractures.

Microseopic examination of the bones revealed a lesion which was striking in its uniformity. The band of cartilage (Fig. 2) which separates the epiphyseal nucleus of ossification from the shaft was much broader than in a normal bone. The cells of the proliferative zone were separated one from another by very little matrix, and the eell bodies-were almost in contact. Although there was a good deal of invasion of the cartilage by blood vessels from the shaft, the columnar arrangement of the cells was well maintained throughout. Because of the increased size and the invasion of the eartilage the cell columns seemed to radiate from the lower margin of the epiphyseal nucleus like the spokes of a wheel (Fig. 3). There was, as a rule, no ealcification of the proliferative zone, though occasionally a few seattered patches of calcified matrix were present to represent a provisional zone of calcification. These calcified areas were usually at the periphery of the bone. The vaseular sprouts which invaded the eartilage were very fine eapillary vessels and were single or multiple. Often the invasion was carried on to a considerable distance from the shaft. Occasionally the invading vessels were arranged in tufts and destroyed wide areas of eartilage betore them. The invasion of the eartilage usually took place, however, along the strands of intracellular matrix (Fig. 4). Cartilage which was directly in contact with the osteoid tissue seemed to have been proteeted against invasion by capillaries from the shaft. Frequently large sinuses, which had thin walls, made up of endothelium and of a few strands of eonnective tissue, were to be found just beneath the cartilage in the metaphysis (Fig. $5)$. At the junetion of the cartilage with the metaphysis the cartilage cells had undergone changes like those which are deseribed as degenerative in the bones of rachitic ehildren. The cell eytoplasm had lost its affinity for basie dyes, and in specimens stained with haematoxylin 
had a pale buff color which was indistinguishable from the staining reaction given by osteoid tissue. The nuelei of the cells were seen to be smaller and more pyknotic as the shaft was approached. Finally, the cartilage cell became buried in the osteoid tissue of the metaphysis, which it apparently helped to form. In other words, this so-called degeneration is in reality, as we pointed out in our description of the bones of rats on diets low in phosphorus and fat-soluble A, a metaplasia of the cartilage cells which results in their change into bone corpuseles.

The metaphysis in these bones was narrow, in contradistinction to the metaphysis in the bones of rats on a diet low in fat-soluble $A$ and phosphate, and appeared to be in much greater degree a product of the diaphysis. The metaphysis was made up of large numbers of trabeculae of osteoid tissue, separated by blood vessels and a delicate reticular tissue containing a few elements from the bone marrow. The spongiosa (Fig. 5) was abundant, and the trabeculae of which it was composed were very numerous and slender. This thin character of the trabeculae was another point of difference between the bones of the rats on the diets low in calcium and those of rats fed on diets low in fat-soluble $A$ and phosphorus. The trabeculae in the latter animals were much thicker, and were fewer in number. The osteoid was broad and often lamellar (Fig. 7). The borders of the osteoid tissue were sharp and clear eut; the cells were widely separated, and their nuclei were small and stained deeply. The osteoblasts which surrounded the trabeculae were flat, closely applied to the osteoid, and altogether resembled the endothelial cells of the blood vessels. In contrast, the osteoid tissue about the trabeculae of the rats on the diets deficient in caleium alone (Fig. 8) was much more ragged. The margins faded off into the surrounding tissue. The nuclei of the bone corpuseles were larger and were very close together, and the osteoblasts which surrounded the bone, instead of being flattened cells, were of low, columnar form, and were often piled up one on the other, to form two or three layers about the trabeeulae. Occasionally trabeculae were seen in the rats on the diets deficient in calcium alone which showed osteoid tissue of both types. Calcification of the trabeculae in these animals was not as dense as in the normal bones. The deposits of lime salts were granular and the calcified zone usually merged gradually into the uncalcified border. The calcified cortex of the shaft was very thin, but the cortex as a whole was usually much thickened by compensatory development of osteoid tissue (Fig. 9) 
Frequently the cortex was canalized and was found in the form of a lattice work. In situations where the bone was under particular stress, e.g., at the sites of museular attachment, or on the concave surface of the bone an enormous amount of osteoid tissue was formed between the periosteum and the original cortex (Fig. 9). This subperiosteal formation of osteoid tissue is analogous to the so-called "rachitic periostitis." It is in reality an hypertrophy to compensate for the diminished strength of the tissue used in building a bone. It is probable that canalization of the cortex of the bone and its growth in the form of a lattice has the same significance.

The bone marrow in the medullary cavity appeared normal in animals on these diets, but in the growing region of the bone the haematopoietic tissue was in a large measure replaced by delicate reticulum.

Many evidences of resorption of the trabeculae, were present. Bones which showed evidences of resorption invariably contained numbers of large cells, the cytoplasm of which was filled with large basophil granules. These cells, which appeared to be derived, in part at least, from small, round lymphoeyte-like forms, were arranged in a definite way along the borders of the trabeculae. They were found in the region of the bone which was being hollowed out to form a marrow cavity, but were not seen in the medulla itself. They were also present in large numbers in the interstices of the bony lattice work which represented the cortex. They were not present in the metaphysis to any extent, and were not found in the centers of ossification. We cannot say what their significance may be, but it would seem as though they must have some function to perform in connection with resorption.

Changes of the nature above described were present through the entire osseous system, but the pathological picture varied in severity in different bones. Those bones which grow most rapidly showed the most marked variations from the normal. The middle tier of ribs, the femur, the radius and ulna, and the tibia and fibula, suffered most severely. It was usual to find a more complete zone of provisional calcification in the cartilages of the vertebrae, phalanges and other smaller bones, even though the cartilages of the ribs and femur were without a vestige of lime salts. The osteoid borders of the trabeculae were widest where the most rapid growth was under way, for example, in the middle tier of ribs and the cuclei of ossification at the ends of the long bones. In the latter situation appositive bone forma- 
tion must be very rapid, since in the process of growth the epiphyseal cartilage has to be replaced by bone during the period when the epiphysis as a whole is enlarging to keep pace with the growth of the entire body.

Broadly speaking, these bones had certain characteristics in common with the bones of rachitic children. The cartilages were not calcified, the epiphyseal line was irregular, and there was a considerable degree of invasion of the cartilage by blood vessels from the shaft. Osteoid tissue was formed in abnormal amounts, and the failure of calcification to occur resulted in weakness of the skeleton, with deformity of the thorax, cranio-tabes, etc. Attempted compensation for the lack of calcification of the bones was seen in the over-production of preosseous tissue and the subperiosteal hypertrophy of the cortex. On the other hand, the changes in the bones which were produced by the above deseribed diets differed from rickets in several important particulars. The cartilage cells retained their columnar arrangement in spite of a considerable degree of invasion by blood vessels. Moreover, as Schmorl (7) has pointed out in the bones of puppies fed on low calcium diets, these bones showed evidences of a much greater degree of resorption than is usually seen in the bones of rachitic children.

If rats which had been confined for some weeks to one of the diets described above were given cod liver oil for a few days before they were killed, a healing process was induced which was evidenced by the formation of a provisional zone of calcification in the proliferative cartilage of the bones. If the animal was allowed to live for a suffieient length of time after the administration of cod liver oil was begun, the rachitic process in the bone was healed, and instead a condition of osteoporosis developed. If cod liver oil was included in the dietary formula from the beginning of its administration, the animals were never normal, and the bones at autopsy were absolutely different from those of rachitic rats. They showed a peculiar pathological condition which will be fully disenssed in a subsequent paper.

When adequate amounts of calcium carbonate were added to the diets, the condition which developed in the skeleton was normal.

\section{Conclusions.}

1. Rats which have been fed on the diets described above, which are low in calcium, but which contain a sufficient supply of the fatsoluble $A$ and have an approximately normal content of phosphate, 
develop a pathological condition of the bone which has certain fundamental resemblances to human rickets. The condition is characterized by increased persistence of the epiphyseal cartilage, its invasion by blood vessels from the shaft, failure in lime salt deposition, the formation of a mixed zone between the eartilage and shaft (the rachitic metaphysis), and the over-production of osteoid tissue. Gross deformities which cannot be differentiated from those eaused by rickets are seen at autopsy.

2. The above described pathological condition differs from rickets, as that disease commonly oceurs in man, in that the arrangement of the proliferative zone of eartilage cells is maintained, and that the evidences of bone resorption in the diaphysis are excessive.

3. The rickets-like condition of the skeleton does not develop, if the deficiency in calcium is compensated for by the addition to the diet of ealcium carbonate.

4. The rickets-like condition never develops, if the animal is allowed to receive eod liver oil, and the administration of cod liver oil, when the condition is well advanced, is followed by healing of the lesion with the formation of an osteoporotic bone.

5. Since this pathological condition in the skeleton is in no way prevented by an amount of butter fat which is amply sufficient to protect the animals against keratomalacia, it is necessary to assume that butter fat exercises a very feeble influence in protecting animals against the development of rickets-like lesions.

1. DibBete, W.

\section{BIBLIOGRAPHY.}

1909. Verhandlung d. deutsehen path, Ges., xiii.

2. McCollum, F. V., Simmonds, NINa, Parsons, H. T., Shipley, P. G., aNd PARK, E. A.

1921. Jour. Biol. Chem., xlv, 333.

3. Shipley, P. G., Pake, E. A., Mccollom, E. V., Simmonds, Nina, Parsons, H. T.

1921. Jour. Biol. Chem., xlv, 343.

4. Shipley, P. G., Park, E. A., McCollom, E. V., and Simmonds, Nina.

1921. Johns Hopkins Bulletin, xxxii, no. 363, 1.

5. MoColuUm, E. V. AND Davis, $M$.

1915. Jour. Biol. Chem., xriii, 181 ; 231.

6. McCollum, E. V., Simmonds, Nina, and Parsons, H. T.

1919. Jour. Biol. Chem., xxxvii, 155; xxxviii, 113.

7. ScHMORL, $G$

1909. Ergebnisse der inneren Medizin und Kinderheilkunde, iv, 403. 


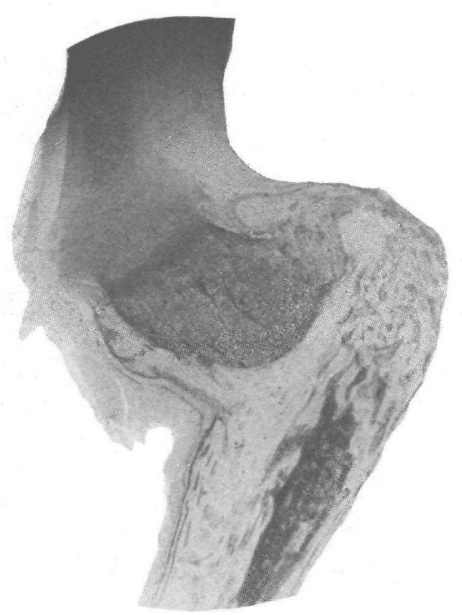

FIG. 1.

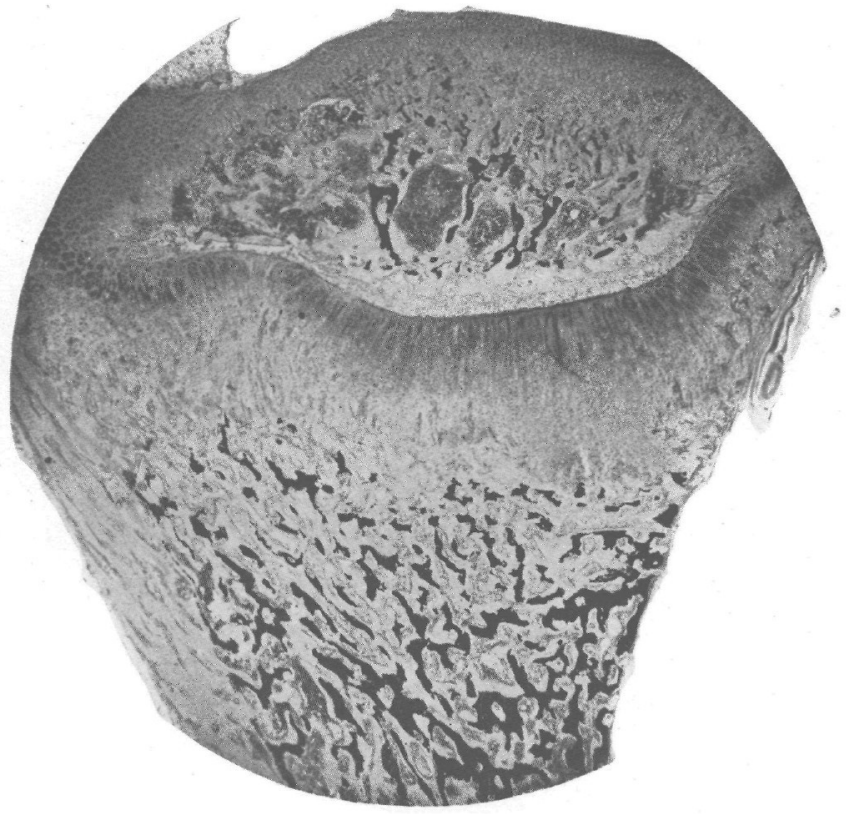

Fig. 2.

PLATE XXV. 


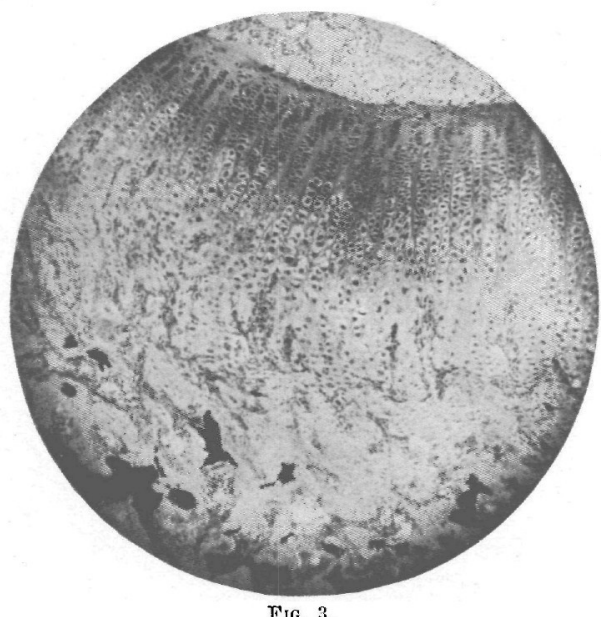

Fig. 3.

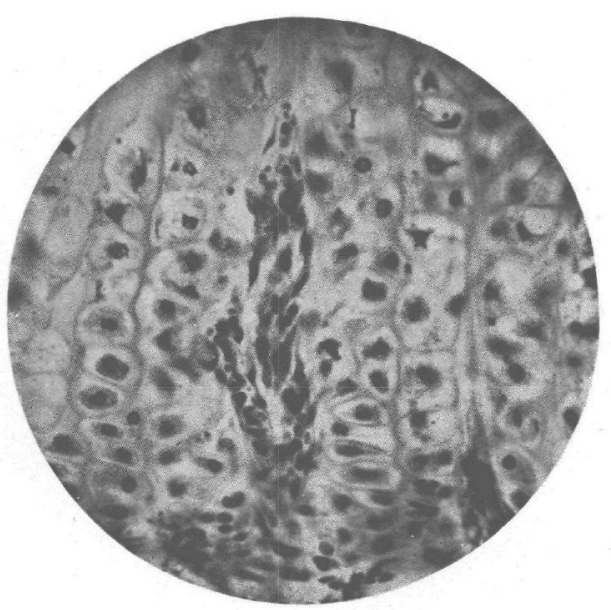

FIG. 4.

PLATE XXVI 


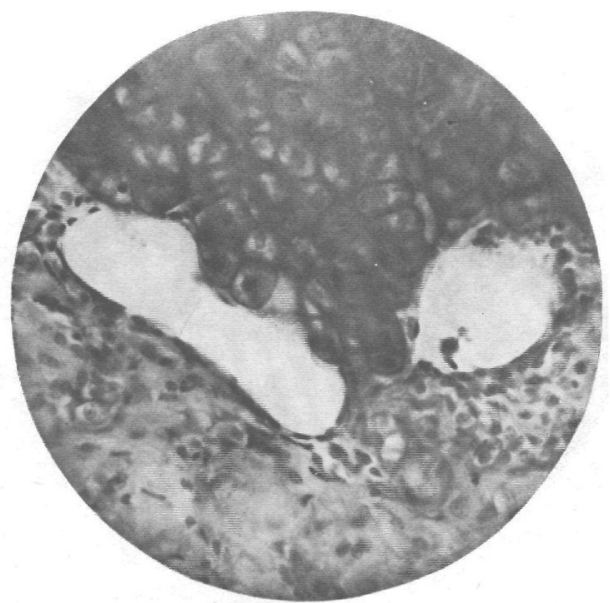

FIG. 5.

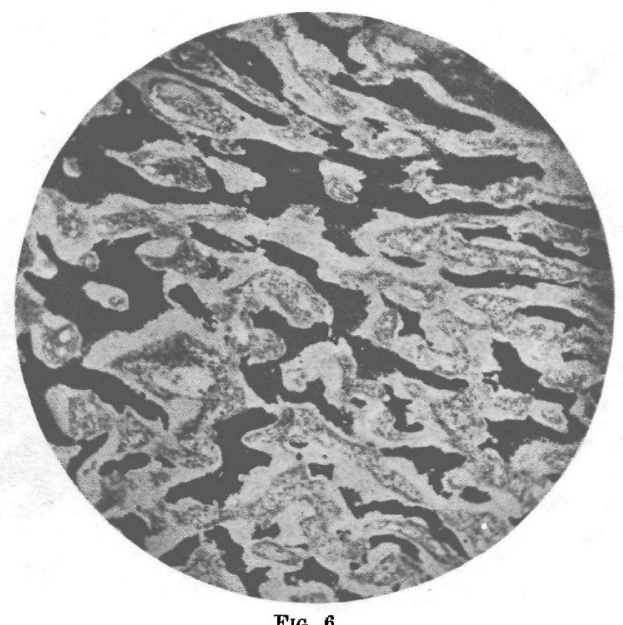

PLATE XXVII. 


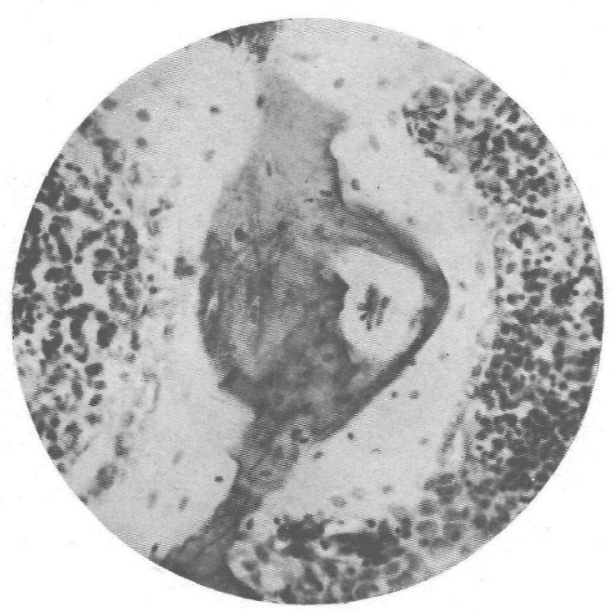

FIg. 7.

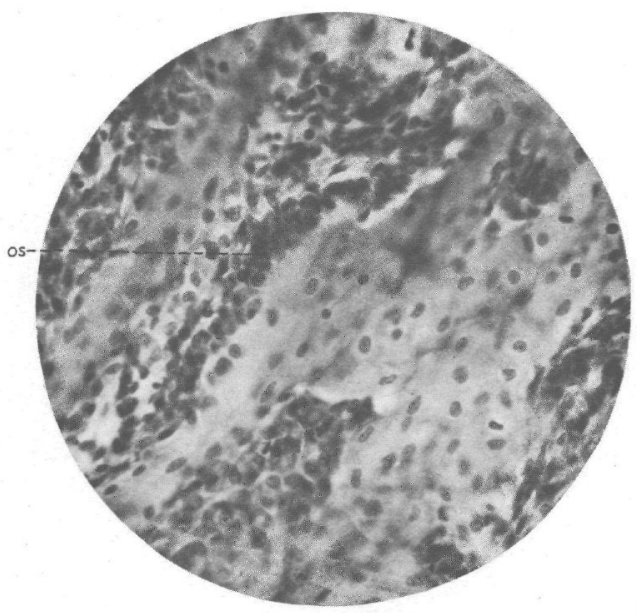

FIG. 8.

PLATE XXVIII. 


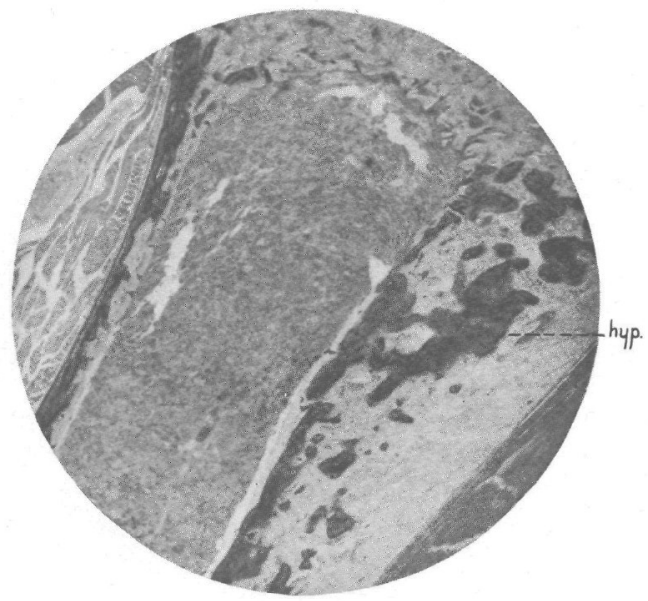

FIG. 9.

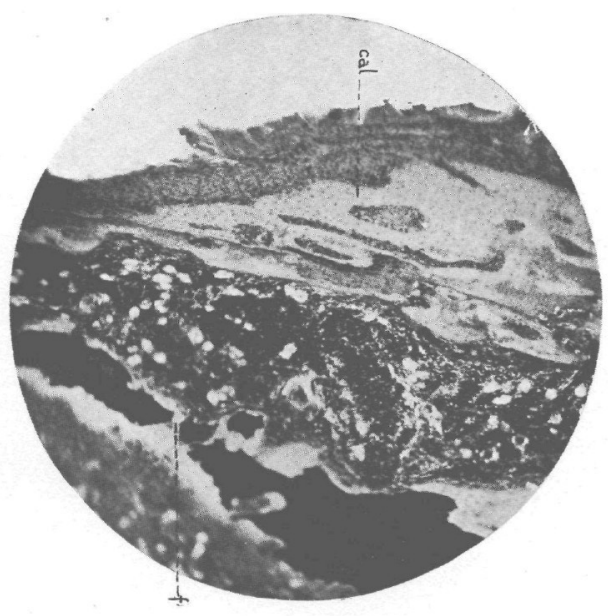

FIG, 10.

PLATE XXIX. 
STUDIES ON EXPERIMENTAL RICKETS.

\section{EXPLANATION OF PLATES.}

\section{PLATES XXV.}

Fio. 1. Longitudinal seetion through the cartilage and shaft of the tenth rib of a rat on a diet low in ealeium, to show the extreme angulation at the costochondral junetion. (Leitz micro-summar objective $135 \mathrm{~mm}$.)

Fig. 2. Photomicrograph of a longitudinal section through the proximal end of the tibia of a rat on the diet of lot 2810. (Same magnification as in figure 1.)

\section{Plates XXVI.}

Fig. 3. This photograph shows the invasion of the lower borders of the epiphyseal cartilage by eapillary vessels from the diaphysis, and the radial arrangement of the columns of cartilage eells. Note the small amount of intereellular matrix and the close apposition of the cells. (Leitz objective No. 3.)

FIG. 4. Photograph with Leitz objective No. 6 showing a capillary blood vessel invading the epiphyseal cartilage. The vascular sprout is forcing its way along the septum which separates one cartilage cell from another.

\section{PLATTES XXVII.}

Fig. 5. Large blood sinuses between the epiphyseal cartilage and the shaft of the bone. (Same magnification as figure 4.)

Fic. 6. Spongiosa of the shaft of the femur from a rat on diet of Lot 2581. Note the numerous, slender trabeculae, each surrounded by a zone of osteoid tissue. (Leitz No. 3 objective.)

\section{Plates XXVIII.}

FIG. 7. High power photomierograph of a trabecula with appositive osteoid. The eells in "the osteoid are widely separated, the nuclei of the greater number are small. The osteoid border is wide and its edges are sharply cut. In the caleified portion of the trabecula is seen the eross section of a perforating blood vessel.

Fre. 8. High power photomierograph (Leitz objective No. 6) to show the resorptive osteoid from the bone of an animal on a diet low in caleium, No. 2581. The osteoid border of these trabeeulae is narrow. Caleification of the trabeculae is very poor. The trabeculas are crowded with large bone corpuscles, and at the border of the trabeeula is seen a mass of osteoblasts four or five eells in depth. (o. 8.)

\section{Plates XXIX.}

Fig. 9. Longitudinal seetion through shaft of long bone to show subperiosteal-hyperplasia (Hyp.).

Fig. 10. Photomicrograph of callus about a spontaneous groen stick frae. ture (f.). The (cal.), which is separated from the cortex by a mass of bone marrow, is almost entirely composed of osteoid tissue. 